\title{
Ko Smal en de grensverschuivingen in het medisch onderwijs
}

\section{Inleiding}

Het Tijdschrift voor Medisch Onderwijs (TMO) wil kort stilstaan bij het vertrek van Ko Smal uit de wereld van het medisch onderwijs. Niet alleen omdat hij, met zijn pensionering, ook vertrekt als redacteur van het Tijdschrift.

Dr. J.A. Smal was medisch onderwijsontwikkelaar van het eerste uur, als medewerker van de afdeling - en later vakgroep - Onderzoek en Ontwikkeling van Medisch Onderwijs, in 1970 gevestigd te Utrecht. Zijn pensionering markeert een dertigjarige periode waarin buitengewoon veel is veranderd in het medisch onderwijs. Hij heeft, met veel anderen, daaraan een belangrijke bijdrage geleverd. Hiertoe behoort het boekje Grensverschuivingen in het medisch onderwijs, geschreven met zijn Utrechtse collega Jaap Gerritsma. In dit boek uit 1974 is voor het eerst systematisch aandacht besteed aan enkele voor het medisch onderwijs belangrijke en nog steeds actuele onderwerpen, in het bijzonder attitudevorming en simulatietechnieken. Het proefschrift van Ko Smal uit 1982, eveneens samen met Jaap Gerritsma geschreven, gaat over de werkwijze van huisartsen en internisten, onderzocht met een interactieve simulatietechniek. De Bayesiaanse techniek die zij in hun onderzoek gebruikten is pas later zo populair geworden in de medische besliskunde. Maar ook aan andere onderwerpen heeft Ko aandacht besteed, op zijn bescheiden wijze. Daartoe behoren toetsing, selectie van studenten en de constructivistische visie op het medisch on- derwijs. Daarnaast begeleidde hij velen in het doen van onderzoek. Dit deed hij in de cursus Onderzoek van Medisch Onderwijs van de Specialisatie Medisch Onderwijs (SMO), maar ook individueel of bij studenten van de Netherlands School of Public Health. Bijdragen van Ko zijn te vinden in het Bulletin Medisch Onderwijs/TMO, verslagen van Gezond Onderwijs Congressen (GOC), het boek Medisch onderwijs in de praktijk en in internationale tijdschriften. Hiermee heeft hij de grensverschuivingen in het medisch onderwijs niet alleen van nabij meegemaakt, hij heeft er ook actief aan bijgedragen.

De redactie heeft enkele auteurs die Ko lange tijd geleden hebben leren kennen, gevraagd een korte impressie van Ko op papier te zetten. Dat deze auteurs deels samenvallen met de redactie van het Tijdschrift is toeval.

\section{Dag Ko!}

De eerste betekenis van smal is - zo zegt mijn Van Dale uit 1976 - van geringe breedte. Dan volgen niet gevuld, mager, klein, gering, schraal en sober. Zo zie je maar weer: nomen est lang niet altijd omen. Want de Smal die ik ken, is in bijna alle opzichten het tegenovergestelde. Alleen van sober ben ik niet zeker.

Hoe lang ken ik Ko Smal nu al? Vanaf 1973, schat ik, maar het kan ook wel wat eerder zijn geweest. In ieder geval startte het met een ICOMO-bijeenkomst in Utrecht, in het medisch-onderwijskundig laboratorium van professor Harm 
Tiddens, een van de founding fathers van de medische onderwijskunde (en later van Maastricht). Daar waren Floris Reitsma, Jaap Gerritsma, Marijke Vleeschdraager (uiteraard), en een vriendelijke reus met de naam Ko Smal. Ik ben daar sindsdien vele malen geweest, en altijd was het inspirerend. En of het nu de oogheelkundige Colenbrander-koppen waren, of OOEVA (het simulatiespel dat docenten en studenten bondig introduceerde in de wondere wereld van het facultaire onderwijsbeleid), je ging er nooit weg zonder iets te hebben geleerd.

Leerzaam was ook het boekje dat Ko samen met Jaap in 1974 publiceerde onder de titel Grensverschuivingen in het medisch onderwijs. Het was bijvoorbeeld mijn eerste kennismaking met het onderzoek van Eron over cynisme bij medische studenten. Dat dat onderzoek allemaal onzin en humbug was, is geloof ik in die tijd aan de aandacht van Jaap en Ko ontsnapt, maar zelf kwam ik daar ook pas later achter (zie Cynisme of Eronie? Een meta-analyse van Erons onderzoek. Bulletin Medisch Onderwijs 1993; 12(3): 117-23).

En dan is Ko voor mij natuurlijk de man van het genereren van toetsvragen per computer. Ik heb geen idee of het vandaag de dag nog een relevant thema is, maar destijds was ik er zwaar van onder de indruk. Ik bekwaamde mij daarom in BASIC en zat uren in de ziekenhuis-dependance van het universitaire Rekencentrum ponskaarten te ponsen en vragen uit te draaien op van die enorme kettingformulieren in een nauwelijks leesbaar lettertype dat uitsluitend kapitalen printte. De kleuters die op de achterkant van mislukte uitdraaien hebben leren tekenen en kleuren, zijn inmiddels de dertig gepasseerd, dus het gaat wel degelijk om historische gebeurtenissen. En dan die ponskaarten, die zijn later door een student-assistent gebundeld tot blokken van zo'n 15 centimeter hoog, en vervolgens in mijn open haard gestookt - maar toen wist ik nog niks van milieu.

Dat heeft Ko dus allemaal teweeggebracht, en uit het bovenstaande mag blijken dat ik daar veel plezier aan heb beleefd. Dank je wel!

\section{Wim Bender}

\section{Een onderwijscyclus voor medische docenten}

In het najaar van 1974 stond ik, als beginnend klinisch onderwijscoördinator, voor mijn eerste gehoor in Leiden om iets te vertellen over mijn Groningse ervaringen in de kliniek voor Verloskunde en Vrouwenziekten met 'een probleemgeoriënteerd juniorcoschap met verschillende didactische werkvormen'. Met deze maiden speech beet ik het spits af in een onderwijscyclus voor medische docenten die Cees van Dorp, destijds hoofd van de Dienst Onderwijs Ontwikkeling van de Faculteit der Geneeskunde in Leiden, had georganiseerd. Dit was dus de eerste professionaliseringscursus voor medische docenten in Nederland.

Zo'n eerste optreden 'in het buitenland' gaat je als broekie niet in de kouwe kleren zitten en ik was dan ook verheugd om te merken dat ik niet de enige spreker was: er was een collega uit Utrecht die over grensverschuivingen in het medisch onderwijs zou vertellen: Ko Smal. Die avond is een bron van blijvende inspiratie voor mij gebleven: ik realiseerde me plotsklaps voor het eerst dat anderen geïnteresseerd waren in wat je doet en ik voelde de geheimzinnige band die personen bindt die bij dezelfde, met enige stress gepaard gaande, gebeurtenis in hetzelfde schuitje hebben gezeten: een band met Ko dus. 
Terugkijkend naar die gebeurtenis van toen is er in die 27 jaar veel gebeurd, er is veel veranderd, maar ook veel hetzelfde gebleven of - beter - weer hetzelfde geworden.

Het medisch onderwijs stond in de jaren zeventig hoog op de agenda. Enkele hoogleraren adviseerden de minister vrijwel rechtsreeks: Querido, Thung, Tiddens, Keuning, Jonxis, Huijgen, Van Es. Temidden van de flower power in het veld stonden zij als mastodonten met visie, die de basis legden voor een helder Academisch Statuut (een Raamplan avant la lettre), een gemotiveerde curriculumverkorting (om ruimte te maken voor een eigen huisartsopleiding), en een gemotiveerde introductie van vroeg klinisch onderwijs met direct patiëntencontact in het derde studiejaar (juniorcoschappen en bedside teaching).

Deze onderwerpen staan nu weer prominent op de agenda in medisch onderwijskundig Nederland. Verschillen zijn er ook. Toen waren het gezaghebbende hoogleraren die de loop der gebeurtenissen vrij direct vanuit een inhoudelijke visie stuurden vanuit de faculteiten; nu zijn het meer instanties als ministeries, de Vereniging van Samenwerkende Nederlandse Universiteiten en de Vereniging van Academische Ziekenhuizen, die minder transparant bepalen hoe het geld wordt besteed, meer vanuit het financieel gekleurd marktperspectief van de gezondheidszorg dan vanuit een academische visie op geneeskunde en het onderwijs daarin.

In de tussenliggende periode hebben de medisch-onderwijskundigen van het eerste uur een wisselvallige tijd gekend: aan de ene kant ontwikkelde de faculteit van Maastricht zich tot een baken van vernieuwing, aan de andere kant waren er de 'andere' faculteiten, die ieder op hun eigen manier reageerden op de bezuini- gingswoede in de jaren tachtig en de overhevelingsoperaties uit de beginjaren negentig. De meeste diensten onderwijsontwikkeling verdwenen.

Landelijk gezien was er een positieve ontwikkeling. De Nederlandse Vereniging voor Medisch Onderwijs (NVMO) is in de afgelopen dertig jaar van kleine amateurclub (in de ware zin des woords) uitgegroeid tot een breed platform voor docenten, medisch-onderwijskundigen in het gehele veld van medische opleidingen in Nederland en Vlaanderen. In de lopende discussie over het opleidingscontinuüm zijn de medische onderwijsontwikkelaars breed vertegenwoordigd in diverse groeperingen die voorstellen maken voor inhoud en structuur van de artsenopleiding en van de vervolgopleidingen. Het zijn niet zozeer eenlingen met visie, maar het is veeleer een corps aan deskundigen dat een bijdrage levert aan het medisch onderwijs in Nederland.

Ko Smal heeft een belangrijke bijdrage geleverd aan de geschetste ontwikkeling. Met zijn grote deskundigheid en belezenheid was hij visionair in de beginperiode, rustig en stabiliserend in de periode dat er stormen woedden in zijn faculteit en nu, in de periode dat de oogsttijd lijkt te beginnen, kijkt hij beschouwend naar de ontwikkelingen en de producten van nieuwkomers: als redacteur van het Tijdschrift voor Medisch Onderwijs en als docent in de scholingscursussen voor medische docenten. Enkele weken geleden heeft hij samen met Albert Scherpbier zijn laatste cursus gegeven en zo is de onderwijscyclus weer rond. Ko begon als docent en hij eindigt als docent ... voor medische docenten.

\section{Herman van Rossum}




\section{De kracht van afstand en betrokken- heid}

Ko leerde ik kennen in 1980. Bij mijn indiensttreding als onderwijskundig medewerker bij de Faculteit Geneeskunde van de Universiteit van Amsterdam vond ik het nuttig een kennismakingsronde te maken langs de onderwijsmedewerkers van alle medische faculteiten. Ko Smal en Jaap Gerritsma leerde ik zo in Utrecht kennen. Ze vertelden me dat ze aan het promoveren waren, iets waar ik ook mee wilde starten. Mij staat van dat bezoek vooral nog bij de nauwgezetheid van de literatuurverzameling die door Ko werd aangelegd. De systematiek waarmee dat gebeurde, en waarmee ook alle verzamelde artikelen terug te vinden waren, getuigden voor mij van een werkelijk professionele, academische attitude. Die attitude heb ik later bij Ko altijd weer teruggevonden. Karakteristiek was dat hij deze gedegenheid steeds paarde aan bescheidenheid. Zó heb ik hem leren kennen, in de GOC-werkgroep, in de TMO-redactie en de laatste jaren in het onderwijsinstituut van het Universitair Medisch Centrum Utrecht. Zijn soms afstandelijke houding maakte het mogelijk om waar dat nodig was ook op het eigen werk in Utrecht kritiek te leveren, vaak met verwijzing naar zijn rijke literatuurkennis. Kenmerkend waren uitspraken als "Nieuw? Ik weet dat dat twintig jaar geleden ook is geprobeerd en beschreven in het British Journal of Medical Education en toen werkte het in ieder geval niet." Die gezonde afstand maakte ook een betrokkenheid mogelijk waardoor in Utrecht Ko, bij iedereen, ook bij de minder van onderwijsontwikkelingen gecharmeerden, een zeer goede naam en onderwijskundig gezag had.

Olle ten Cate

\section{Rustig en bescheiden?}

Twintig jaar geleden kwam ik als 'brugpieper' in het medisch onderwijs op bezoek in Utrecht. Ik keek op tegen drie senioren in het medisch onderwijs. Ko Smal, Jaap Gerritsma en Casper Bleys. Het is mede aan hun stijl en omgangsvorm te danken dat het 'brugpiepergevoel' niet lang duurde. Ik herinner me nog twee dingen uit die jaren: Ko en Jaap volgden een cursus journalistiek schrijven en de rust en de bescheidenheid waarmee Ko zich presenteerde. Als redacteur van het Bulletin Medisch Onderwijs, later het Tijdschrift voor Medisch Onderwijs, heb ik veel producten van de hand van Ko mogen beoordelen. Het is voor mij duidelijk dat Ko bijzonder goed kan schrijven. Korte zinnen, helder taalgebruik, een goede lijn in het verhaal, methodologisch verantwoord, voorzien van adequate referenties, et cetera. Er is wellicht een relatie met de gevolgde cursus, maar dat weet ik niet zeker. Bovendien zou Ko gelijk zeggen: "Een relatie betekent niet dat er een causaal verband is". Een voorbeeld is het hoofdstuk over selectie in het boek Medisch onderwijs in de praktijk. Het onderwerp selectie zorgde in die tijd voor veel emoties. Ook was en is er een meer emotioneel dan rationeel verband tussen selectie en kwaliteit. Ko legt het probleem heel duidelijk uit. Met behulp van een vierveldentabel laat hij zien dat er zowel studenten zijn die ten onrechte worden afgewezen als studenten die ten onrechte worden toegelaten. Het goede aan deze uitleg is dat vanuit de emotionele benadering van selectie vaak alle aandacht gaat naar de ten onrechte niet toegelaten studenten, terwijl vergeten wordt dat er ook studenten zijn die ten onrechte wel worden toegelaten. Bovendien kon hij zo uitleggen wat de winst van selectie is. Dat is een belangrijke insteek, omdat vaak vergeten wordt 
dat de tijd en energie die aan selectie worden besteed niet meer aan onderwijs besteed kunnen worden. Het budget kan echt maar één keer uitgegeven worden.

Over mijn eerste indruk van rust en bescheidenheid heb ik inmiddels voldoende jaren kunnen nadenken, terwijl ik met Ko in verschillende functies heb samengewerkt. Ik denk nu dat de bescheidenheid wel klopt, maar de rust niet helemaal. De rust lijkt meer buitenkant dan binnenkant en dat siert hem ook. In de woelige tijden die hij heeft meegemaakt, zijn het veeleer zijn vermogen tot relativering en pragmatisme dan 'rust' die gemaakt hebben dat hij door kon gaan.

Als docenten van de SMO-cursus Onderzoek van Onderwijs hebben wij de afgelopen jaren veel samengewerkt. Bij de opzet van de cursus in 1995 hebben de gedachten van Ko over constructivisme en zijn grote ervaring met dergelijk onderwijs een grote rol gespeeld. Een hele oude papieren 'vertakte' simulatie van een onderzoek met tal van keuzemogelijkheden en een daaraan gekoppeld verloop van het onderzoek bleek nog goed bruikbaar te zijn om de cursisten zelf valkuilen van onderzoek te laten ervaren. Ko zijn grote kennis van de methodologie en literatuur bleek uit de adviezen aan de cursisten. De adviezen werden gekenmerkt door relativerende opmerkingen en het vermogen om het onderzoek te beperken, zodat de haalbaarheid vergroot wordt. Als mederedactielid van TMO zijn mij vaak dezelfde dingen opgevallen. Ooit ben ik opgeleid als dokter en daarna, als autodidact, ben ik nog steeds aan het leren over onderwijs. Op het terrein van Ko ben ik natuurlijk nog steeds een 'brugpieper'. Zo voelt het niet, niet gebukt onder die volle rugzak van de brugpieper, want met Ko kun je echt samenwerken. Van hem kun je leren en hij wil van de ander leren. Ko, bedankt hiervoor en ik zal dat missen. De afstand tot het medisch onderwijs was je de laatste maanden al aan het nemen en dat is ook goed, want er is ook wat anders om van te genieten.

Albert Scherpbier 